\title{
A THEORETICAL APPROACH TO PROCESS OF SELLING IN THE MODERN UNDERSTANDING
}

\author{
Assist. Prof. Dr. Yakup DURMAZ 1 and Ali KARAMAN
}

${ }^{1}$ Faculty of Economics Administrative and Social Sciences, Hasan Kalyoncu University, Havalimanı Yolu Üzeri 8. Km. Gaziantep, Turkey. Tel: 90-342-211-8080. E-mail:

yakup.durmaz@hku.edu.tr and yakupdu@hotmail.com

${ }^{2}$ Phd.Student at Department of Bussiness Administration of Hasan Kalyoncu University. E-mail: dralikaraman@gmail.com

\begin{abstract}
Selling and buying are inevitable parts of our lives. As a member of a society, we need to buy and/or sell things in our everyday life. The things that we sell or buy do not have to be concrete objects. Information exchange in the society, or even the ideas people use to introduce themselves can be considered as selling ideas. However, in this study we focused on selling concrete objects rather than abstract things. We tried to explain how we understand our customers' needs and demands and shared the way we meet their needs and demands by presenting our products. Selling is a process which starts way before we meet our customers. A salesman should do a proper research about his/her target before the selling and determine the needs and demands of customers in order to present appropriate products. Moreover, a salesman needs to have the skill to handle the problems with customers. In this study, the selling process and the things a salesman should do in each and every step of this process were explained.
\end{abstract}

Key Words: Selling, Selling Process, Handling Objections, Listening actively, Asking Questions.

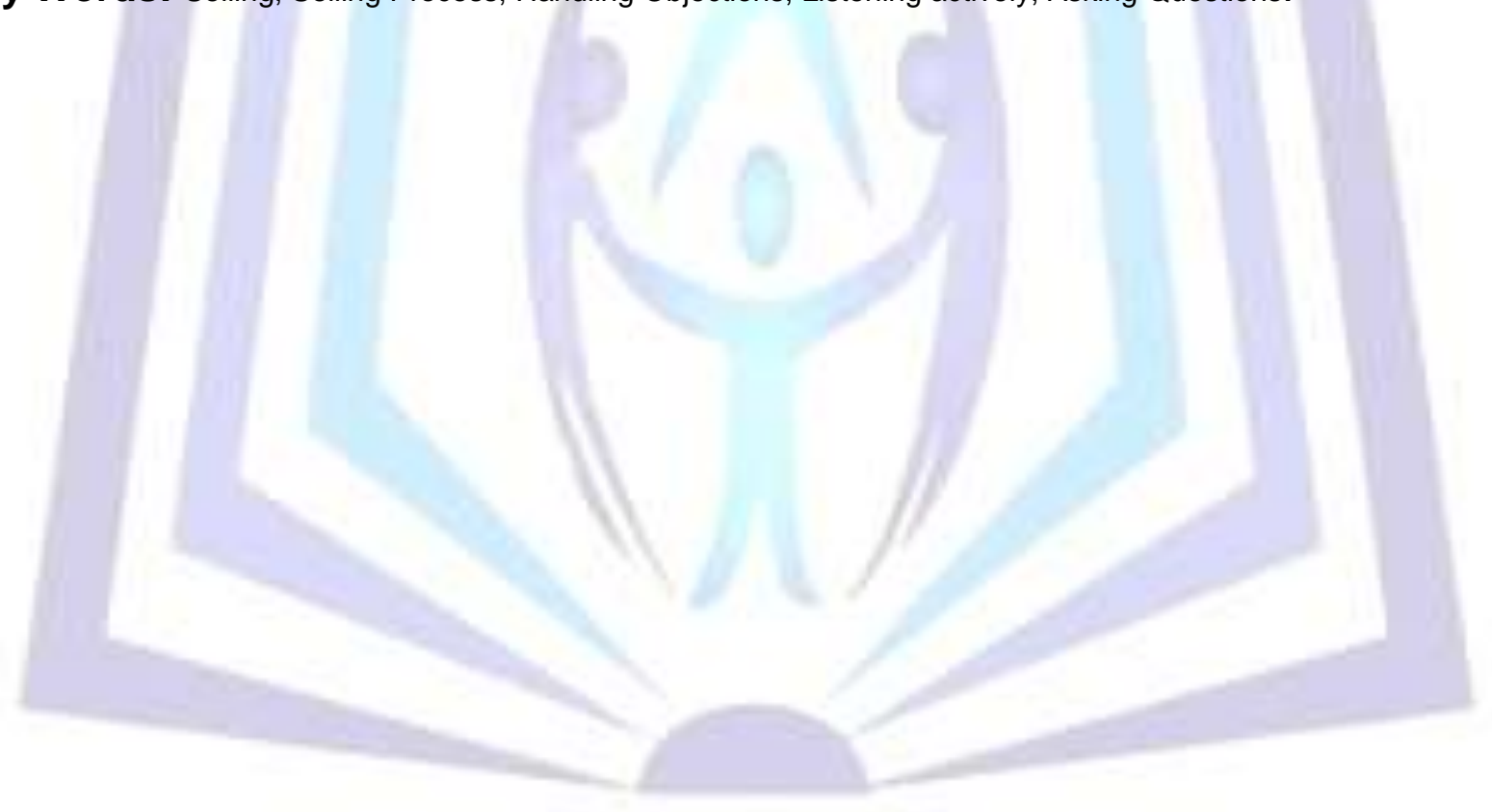

\section{Council for Innovative Research}

Peer Review Research Publishing System

Journal: International Journal Of Management \& Information Technology

Vol . 10, No 7

editorsijmit@gmail.com

www.ijmit.com 


\section{INTRODUCTION}

It is crucial for a salesman to know the selling process and how this process works. Selling takes place after a series of research and analysis. The main aim of selling is to understand the customers' demands and serve the products accordingly. Selling includes a several steps in terms of process. Selling process, therefore, represents the all steps which can be used in areas related to selling.

In today's world of competition, there are opponents who/which are able to meet the demands of customers and their numbers are increasing. In this competitive environment, we need to turn the odds to our advantage by using selling process as a skill in order to serve the most appropriate products and help customers decide which product to buy.

The purpose of this study is to examine each and every step of the selling process in order to have and to be able use proper selling skills. First of all, the outline of the process of selling was explained and then all the steps of selling process was examined in detail.

\section{BASIC CONCEPTS ABOUT SELLING}

Selling is a device which connects the buyer and the seller directly. (Bahçe, Uslu ve Sevim, 2013: 11). Salesman is a person who is able to use psychological, social and economical factors which affects the buying decision of a customer for product/service and business. (Bahçe, Uslu ve Sevim, 2013: 16). As understood from the definition, seller is in the place of a decision maker. Customer, is the most important person for companies, who has needs and demands and has to make a decision to buy products or services to meet them.(İslamoğlu ve Altunışık, 2009: 40). Product, package, color, price, brand are the set of abstract and concrete qualifications which includes the salesman's service and image (Altunışık, Özdemir ve Torlak, 2006:132). In fact, a product is an abstract or a concrete thing which has a potential of meeting the customer's demands and ready to be served by the sales representative.

\section{HISTORY OF SELLING}

It is accepted that the process of selling started way before the money was invented by means of barter. In the next eras people used valuable mining materials to meet their needs. In 7th BC, with Lydian inventing the money as metallic currency, exchange became easier. With the invention of soft money towards the end of the 1600s, the concept of "value" came into view and made the process of selling became much easier. (Bahçe, Uslu ve Sevim, 2013: 3 ).

At the beginning of 1950's, a new marketing philosophy, in which products and services arranged according to the demands and needs of customers, started to be used instead of compulsory techniques.(Odabaşı ve Oyman, 2002: 61).

Starting from 2000's, responsibilities and duties of salesmen have increased. Convincing customers and solving customers' problems depends on the skills of salesmen. Thanks to the globalization and the Internet, the opportunities for getting information about products and services have varied and increased. In today's world of competition and urbanization, people get more individualized. Therefore, salesmen and sale representatives need to function as a bridge between companies and customers. In short, sale representatives are professionals who try to balance the relationship between customers and companies according to this new understanding of consumers. (Bahçe, Uslu ve Sevim, 2013: 10).

\section{PROCESS OF SELLING}

Selling, is not just a simple process, it consists of several stages. These stages begin with the selection of target mass and research, that is before meeting customers in person. Then customers are met and their needs and demands are determined. After the production of products and services which are determined according to the needs and demands of customers, the last stage; "undertaking" comes. In the undertaking stage, if buying does not occur because of complaints of customers, these problems are handled and analyzed carefully so that buying can happen smoothly. In the Table 1 , stages of selling process are shown in a diagram. 


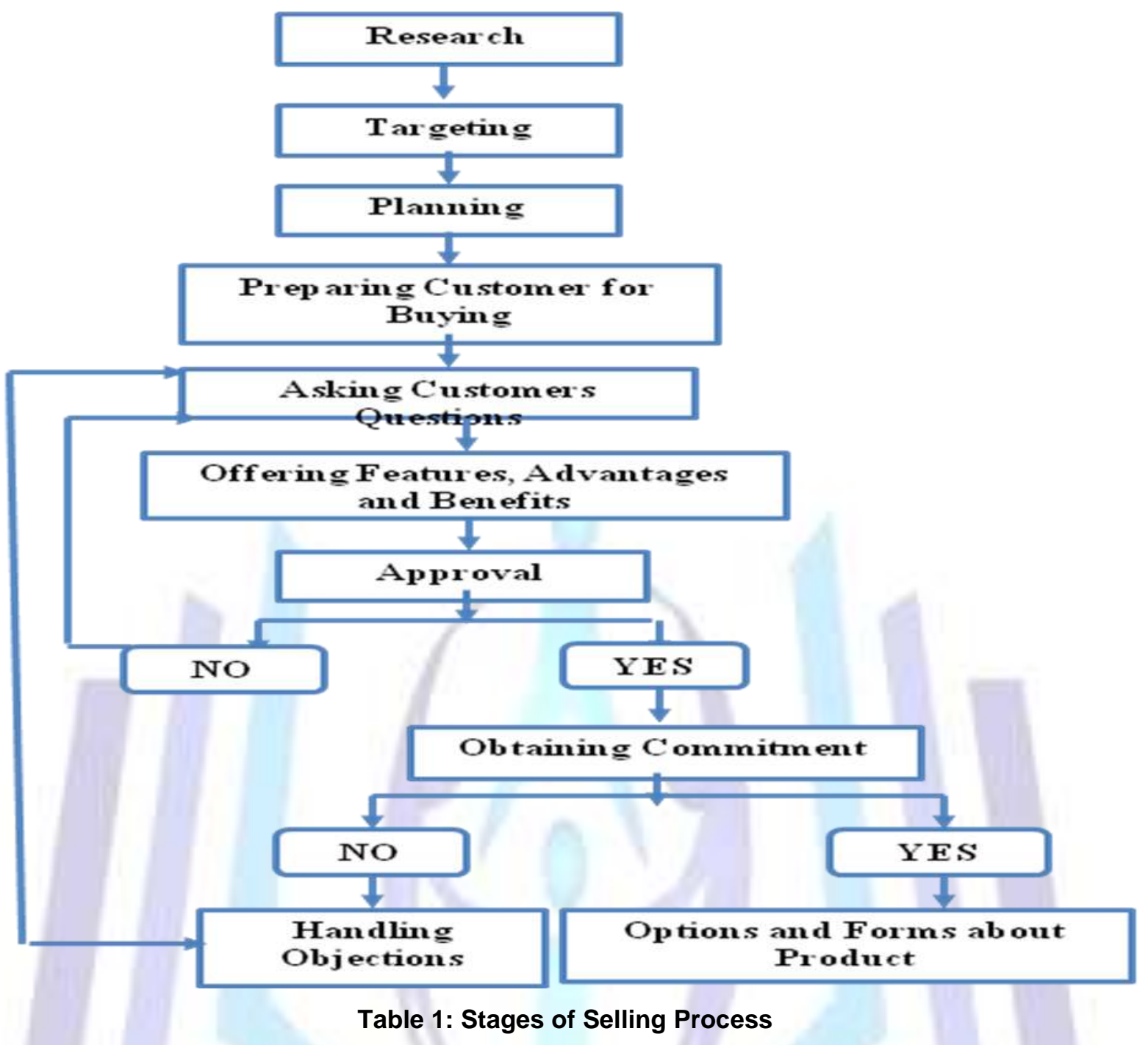

As shown in the Table 1, process of selling includes a number of stages. In the following titles, every step of these stages will be explained and discussed.

\subsection{Research}

The very first stage of selling process is "research". It is useful to group possible buyers and list the things we know about them in terms of getting to know customers. In order to understand and reach buyers, it is crucial to create a content strategy and data bank. (Scott, 2010: 56 -57).

In this stage, salesman does a research about possible customers and finds them to determine their behaviors and needs. A salesman needs to be fully informed about his/her rivals and her/his own product before s/he meets customers. S/he also has to gather as much information as possible about customers (Yükselen, 2008: 385,393). The more we know about the customers and their environment, the better we serve them (Mazur ve Miles, 2009: 16). After this stage is completed properly, we can pass on to "targeting" stage.

\subsection{Targeting}

It is very important to use time properly and efficiently and to do that priorities need to be set first. Whatever our priorities are, we can reach them easily by using the time properly. The time should be used for the most important targets. It needs to be divided so well that it can be profited in the best way. Therefore, in this stage we need to spare time to the possible and important customers first. (Engin, 2006: 18 -19). The following stage is planning, of which importance differs from customer to customer.

\subsection{Planning}

In this stage SWOT ( Strengths, Weaknesses, Opportunities, Threats) analysis should be made. SWOT analysis consists of internal and external environmental analysis. We need to know our strengths, weaknesses, opportunities and threats in order to assess our situation in terms of rivals and customers and to do a better analysis of our environment (Kotler, 2000: 46). SWOT analizi geleceğe uzanan yolların daha açık ve net olmasını sağlar (McDonald and Payne, 2006: 45). We also 
need to analyze our rivals so that we can make a difference to control competition. We need to determine and state our different aspects from our rivals. Customers' choices need to be determined in order to prepare questions to be asked in the questioning stage (Tulgar, 2010: 54).

Planning enables sales representative to be prepared in the presence of any kind of problem. In this way s/he can be in control of the selling (Yeniçeri ve Yücel, 2009: 139). The basic condition of planning is to focus on customers. "Focusing on customers" necessitates getting current information and data about customers in order to learn their demands, needs, perception about our and rivals' products (Kourdi, 2014: 225). We can categorize customers with these information. Also, we can set selling targets while planning. Some may think that setting selling goals is unnecessary since conditions of environment and future change; however, selling goals may be useful in terms of providing companies with flow of selling Buttle, 2009: 157 -159). After planning stage, target customers are prepared to be met.

\subsection{Preparing Customers for Selling ( The Approach )}

In this stage, sales representative and potential customers come face to face. This stage has a very important role in the success of selling since it is the time when the first impression is made on customers. Trust means not creating a negative effect on the other side and behaving in a predictable way. (Hollensen, 2010: 202). Author (Backwith, 2009: 21), states that customers buy from optimistic people since they feel comfortable around such people. Customers also buy from honest people since they know they can trust an honest person like they trust a safe vault.

Moreover, if customers have a negative opinion about anything, this is the stage to remove them in order to set a trustworthy relationship with customers and gain their loyalty (Smith ve Rutigliano, 2010: 140-141). Gaining customers' trust and maintaining it is really important in terms of selling process (Mazur ve Miles, 2009: 100). After this stage, the crucial point of selling "questioning customers" stage comes.

\subsection{Questioning Customers ( The Needs Assessment )}

Questioning stage starts when customers are ready to talk about selling and selling process. Needs of customers are discovered in this stage. Questioning is enough to learn customers' needs in the first meeting (Vural, 2004: 335).

In today's world of globalization, determining customers' true needs is crucial in terms of selling process. Most of customers confuse their demands and wishes for what they really need and therefore direct their attention to the products they don't need. Focusing on determining the true need of customers rather than what they say they want is really important in order to be able to direct customers accordingly (Bahçe, Uslu ve Sevim, 2013: 85).

Sales representatives are trained to ask proper questions for determination of needs. Open ended questions are good for determining the true needs of customers since customers share their own ideas in that way. Customers' answers are more important than questions since those answers help us understand customers (Waugh, 2004: 86).

Question Types Regarding the Determination of Needs (İslamoğlu ve Altunışık, 2009: 103);

\section{Situational Questions}

How often do you change this piece?

Other than general manager whose approval is needed?

Questions regarding determination of problems

How long was the average lifespan of pieces before?

Does lifespan of this piece change among divisions?

Questions regarding the importance of the problem

Approximately how much loss this piece caused because of malfunctioning?

Can this malfunction affect the quality directly?

\section{Approval questions}

If I prove that you can decrease your malfunction rate to $25 \%$ with this piece, would you consider to buy it? After the needs are determined, conveying the features and advantages of products which are appropriate for their needs comes next.

\subsection{Offering Customers Features, Advantages and Benefits ( The Presentation )}

Feature means a structural and functional distinction a product has. In this stage, some features and benefits of the products which are chosen for the needs of customers need to be explained. Each and every one of the products has different features. Therefore, if features of a product meets the need of a customer then the selling takes place. For this reason, presentation of features need be able to meet customers' needs. (İslamoğlu ve Altunışık, 2009: 104). Tulgar (2010: 55) states that the right goods is the one which has the features a customer wants. That is, customers' wants are very significant and need to be regarded carefully. 
Customers will not listen to you if they feel that what you are saying is useless for them. If they sense that you are just trying to draw their attention for nothing they will lose their interest. Therefore, avoiding details and not going off the topic is important when presenting the products (Carter, 2000: 22 -60). After conveying features, benefits of products can be explained additionally (Spini, 2010: 130).

Pointing out the benefits along with the features of a product and highlighting the different aspects by comparing it with rival products are very important. One should act quickly and be determined to impress and satisfy the customer. Otherwise, people may think that you are meticulous (Kourdi, 2014: 241). Also, not underestimating rivals while emphasizing the features they do not have is very important, since customers do not want to how bad your rival is, they want to know how good your product is(Kawasaki, 2009: 58).

Nowadays, customers are well-educated and well-informed about markets. They can check the products they want through the Internet. Thus, providing customers with features and benefits of products in a proper way, avoiding any kind of bad comments about rivals.(Mazur ve Miles, 2007: 37).

After customers are presented with features and benefits of products, their decision about buying is asked, this is called recessional approval. If the customer approves buying commitment is obtained, if s/he says no then we go back to questioning stage since this means that there is a problem which needs to be solved. Below there is a table which shows features, advantages and benefits of some products.

\begin{tabular}{|l|l|l|l|}
\hline \multicolumn{2}{|l|}{ Samples about Product Features, Advantages and Benefits } \\
\hline Product & Feature & Benefit & Advantage \\
\hline SLR camera & $\begin{array}{l}\text { Variable focus } \\
\text { lens }\end{array}$ & $\begin{array}{l}\text { Opportunity to take picture in } \\
\text { different dimensions and options. }\end{array}$ & $\begin{array}{l}\text { Taking close-range and long } \\
\text { distance pictures from the } \\
\text { same place. }\end{array}$ \\
\hline Laptop & Long battery life & $\begin{array}{l}\text { To be able to use the laptop for a } \\
\text { long time while travelling. }\end{array}$ & Saving from time. \\
\hline $\begin{array}{l}\text { Navigation } \\
\text { for cab }\end{array}$ & $\begin{array}{l}\text { Sound alarm and } \\
\text { wide screen. }\end{array}$ & $\begin{array}{l}\text { To be able to understand the } \\
\text { route information clearly. }\end{array}$ & $\begin{array}{l}\text { Safe drive and minimum } \\
\text { accident rate. }\end{array}$ \\
\hline
\end{tabular}

Table 1: Features, advantages and benefits of sample products.

\subsection{Obtaining Commitment}

This stage constitutes $10 \%$ of the presentation (Bahçe, Uslu ve Sevim, 2013: 85). In this stage, the summary of selling presentation is made by telling features, advantages and benefits of products briefly and customers are asked to make a decision. If the answer is yes, forms and options of products are presented and the selling is closed. If the answer is no then it means that there is an objection to the selling. Therefore, we need to go back to the questioning stage. In this way we can learn about the reason of the objection and solve the problems in order to finalize the selling positively.

If customer is eager to buy the product $\mathrm{s}$ /he will ask about the how long the completion of selling will take. In such cases, the right thing to do is to close the sale properly. (Kawasaki, 2009: 184). While obtaining commitment, the most important thing is to listen to the customer carefully. In order to know customers' statements about the product whether it is positive or negative, and if it is negative to learn the reason why, listening is very significant. The answer "No" suggests that there are objections to be handled. Therefore, when we go back to the questioning stage in order to solve the problems and understand the reasons behind objections we need to listen customers actively.

\subsection{Active Listening}

Though it may seem easy, listening is a difficult task. It requires constant attention and patience. The longer the conversation gets, the shorter the listener's attention span becomes. It is known that if one is not a good listener s/he is not good at making people listen to him/her either. One of the biggest mistakes of selling is not listening to customers carefully, as a result of which we fail to understand the true need of customers. This leads sale to unfavorable outcomes.(Bahçe, Uslu ve Sevim, 2013: 74).

Salesman need to give feedback to customers after listening to them (Vural, 2004: 334). One condition of active listening is to give feedback. Feedback need to be revised in order to check whether it is sufficient to convey the message. (Benton, 2007: 157). There are two fundamental needs of humans; one is to be understood and the other one is to be cared about (Baltaş, 2007: 38). If the customer trusts the salesman, s/he will convey his/her ideas directly. As a result of active listening, salesman get to know customers better, which affect the selling process in a positive way. This, once again, points out the importance of listening (Waugh, 2004: 67).

\subsection{Handling and Preventing Objections}

When a customer objects something about the product we need to remove that objection so that the selling can take place. If the objection is caused by the customer's hesitations and s/he does not want to buy the product than this means 
the objection is fake or hidden. Hidden objection means that the customer does not want to buy the product so his/her objections may not reflect their true feelings (Spini, 2010: 157).

In the process of selling, objections play an important role. The rate of success in selling depends on the success in handling the objections. Objections reveal customers' hesitations and concerns while buying a certain product. Objections need to be handled in several steps. (Bahçe, Uslu ve Sevim, 2013: 159).

\begin{tabular}{|c|c|c|}
\hline \multicolumn{3}{|c|}{ Most Frequently Encountered Objections And Handling Obtions } \\
\hline $\begin{array}{l}\text { Objection } \\
\text { Type }\end{array}$ & İtirazın şekli & Solutions \\
\hline Cost & Expensive price of products. & $\begin{array}{l}\text { Accepting the objection, offering the reality. Making a price- } \\
\text { value connection, pointing out the efficiency, emphasizing } \\
\text { the economic life of the product and service quality. }\end{array}$ \\
\hline Product & $\begin{array}{l}\text { Quality regarding the usage of the } \\
\text { product. } \\
\text { Not knowing the product or the } \\
\text { service. } \\
\text { Lack of interest in the product. }\end{array}$ & 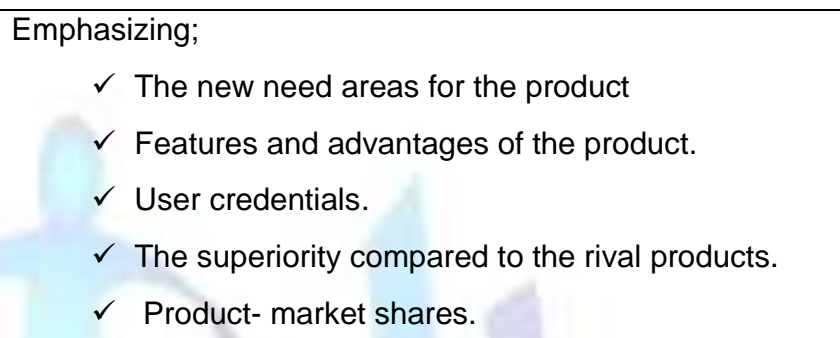 \\
\hline Company & $\begin{array}{l}\text { Not knowing the company. } \\
\text { Unfavorable experiences. }\end{array}$ & $\begin{array}{l}\text { Emphasizing the credentials and improvements of the } \\
\text { company. }\end{array}$ \\
\hline Time & Limited time. & Briefly explaining the advantages. \\
\hline Salesman & $\begin{array}{l}\text { Lack of experience. } \\
\text { Failing to gain customers' } \\
\text { confidence. }\end{array}$ & $\begin{array}{l}\text { Contributing salesmen personal development by focusing } \\
\text { on their education. }\end{array}$ \\
\hline
\end{tabular}

\section{Table 2: Customer Objection Types and Handling Options ( Bahçe, Uslu ve Sevim, 2013: 154)}

Salesman need to determine solutions to handle different kind of objections. As seen in Figure 2, ways to handle the customer objections will be efficient to learn (Bahçe, Uslu ve Sevim, 2013: 155 ).

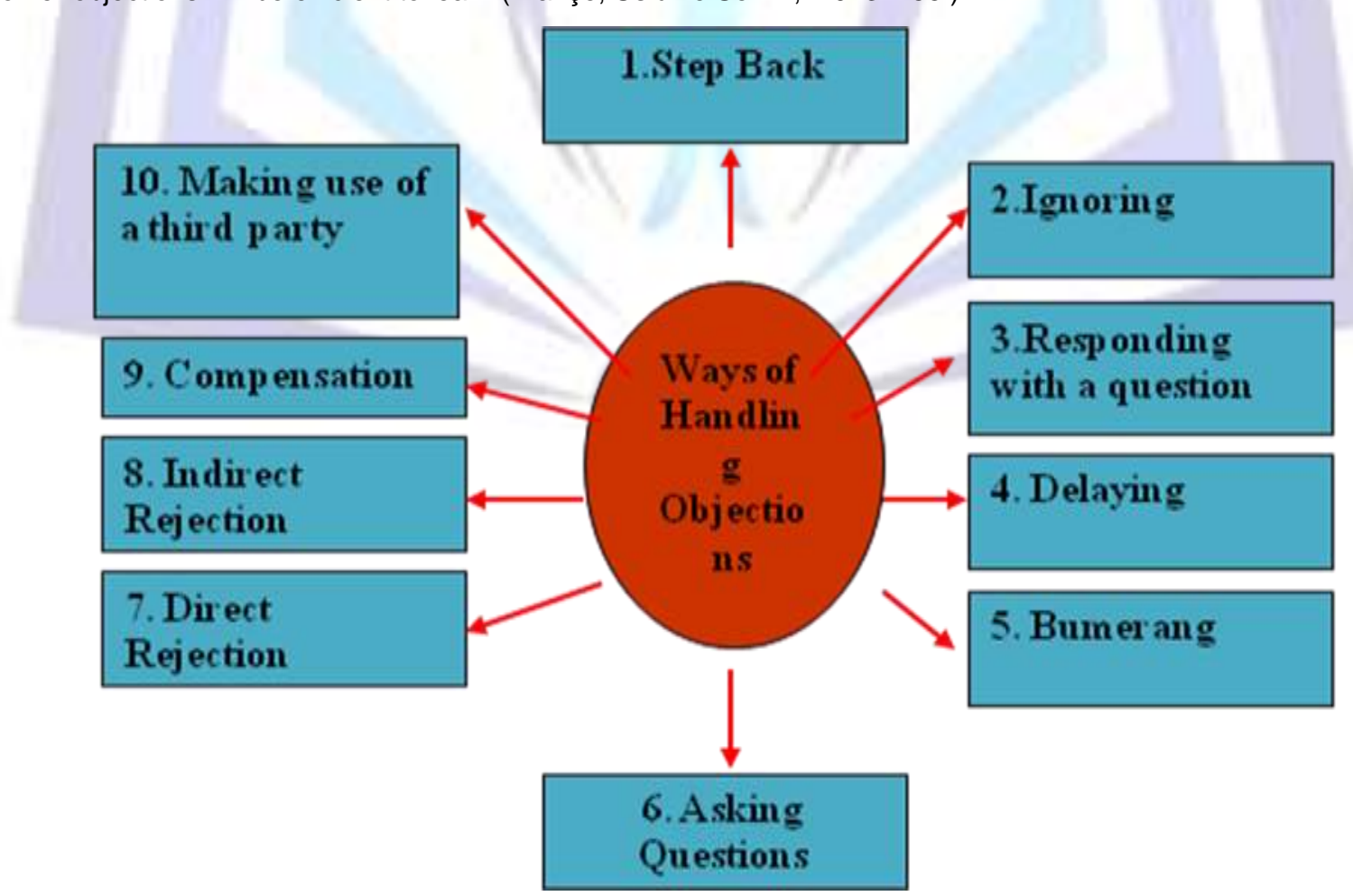

Figure 2 : Ways of Handling Objections ( Futrell, 2011: 385 ). 


\section{ISSN 2278-5612}

Below there are explanations about ways of handling objections (Bahçe, Uslu and Sevim, 2013: 156):

1. Step back: When first encountered the complaint, show customer that you understand them and they have every right to complain. At the same time, it is important to emphasize the product's features which can defeat complaint(s)

2. Ignoring: If it is realized that the objection or the complaint is just an excuse for not buying the product, then it can be ignored. This can be caused by customer's lack of knowledge about the product. Therefore, customer can be briefly informed about the product.

3. Responding with a question: Objection can be responded with a question in order to show that you are interested in their ideas and also to make the objection/complaint clear.

4. Bumerang: In this method, we turn the reason of complaint into the reason of buying the product.

5. Questioning (Asking Questions ): Customer is asked questions in reply to his/her objection(s) so that s/he can clear his/her mind about objection (s).

6. Direct Rejection: Some customers may have wrong information about the company or a certain product. A salesman, preferably an experienced one, should kindly state that $\mathrm{s} /$ he is mistaken or misinformed.

7. Indirect Rejection: This method is also called "Yes, but..." method. Objections are rejected in a very sincere and soft way. At first, objection is seemed to be accepted, yet afterwards it is rejected by providing necessary justifications.

8. Compensation: This method is used when the objection is thought to be right. Then the objection is accepted and tried to be compensated by providing some advantages to the customer.

9. Making use of a Third Party: If the customer is continuing to complain, then the objection is tried to be interpreted with the help of a third party.

It is a very effective way of convincing customers to make use of other people's experiences and suggestions (Bahçe, Uslu ve Sevim, 2013: 156).

\section{CONCLUSION}

To understand and to be able to apply the process of selling will turn the knowledge about selling into a skill. Therefore, selling process plays an important and efficient role in different selling and promotion activities.

The most important part of selling is to handle objections and asking questions. Questions provide us with information about customers and the direction of selling. The way we handle objections and complaints can affect selling in a positive or a negative way. However, all the stages may not be applied altogether; therefore meeting customers helps us decide where to begin.

In this study, basic information about the process of selling was tried to be explained for sales representatives to have knowledge and skills about the selling process. One thing which should not be forgotten is that experience is very important in selling and success rate increases when knowledge (theory) turns into a skill (practice).

\section{REFERENCES}

1. Altunışık, R., Özdemir, Ş. ve Torlak, Ö. (2006). Modern Pazarlama İstanbul:Değişim Yayınları.

2. Batlaş, A. (2007). Yeni Yöneticinin El Kitabı (3.Basım). İstanbul: Remzi Kitabevi A.Ş.

3. Bahçe, A. S., Uslu, A. ve Sevim, N. (2013) Kişisel Satış Teknikleri. Eskişehir: Anadolu Üniversitesi

4. Benton, D. A. (2007). Ceo Koçunun Sırları. İstanbul: Pegasus Yayınları.

5. Beckwith, H. ve Backwith, C. (2009) Ben A.Ş. İstanbul: Optimist Yayın Dağıtım.

6. Buttle, F. (2009). Customer Relationship Management (2nd. Ed). U.S.A: Elsevier Ltd.

7. Carter, A. (2000). Communicate Effectively. Gretna- U.S.A: Pelican Publishing Company Inc.

8. Engin, C. (2006). Zaman Yönetimi. İstanbul: Optimist Yayınları.

9. Futrell, C. M. (2011). Fundamentals of Selling-Customer For Life Thought Service(12th. Ed). New York: McGraw-Hill.

10. Hollensen, S. (2010). Marketing Management- A Relationship Aproach. England: Pearson Education Limited.

11. İslamoğlu, A. ve Altunışık, R. (2009). Satış ve Satış yönetimi. Sakarya: Sakarya Yayınları.

12. Kawasaki, G. (2009). Kendi İsini Kurmak İsteyen Girişimcinin El Kitabı. İstanbul: Kapital Medya Yayınları A.S.

13. Kottler, P. (2000). Marketing Management Milenium Edition (10th. Ed). New Jersey: Pearson Custom Publishing

14. Kourdi, J. (2014). İs Stratejisi. İstanbul: Türkiye İş Bankası Kültür Yayınları.

15. Mazur, L. and Miles, L. (2007). Conversations With Marketing Masters. England: John Wiley \& Sons Ltd.

16. Mazur, L. ve Miles, L. (2009). 12 Pazarlama Ustasından Pazarlama Dersleri. İstanbul: Kapital Medya Hizmetleri A.Ş.

17. McDonald, M. and Payne, A. (2006). Marketing Plans For Service Businesses (2nd. Ed). U.K. Butterworht- Heinemann Elsevier.

18. Odabaşı, Y. Oyman, M. (2002). Pazarlama İletişimi Yönetimi.Istanbul: MediaCatYayınları.

19. Scott, D. M. (2010). Pazarlama ve İletişimin Yeni Kuralları. İstanbul: Capital Medya Hizmetleri A.Ş.

20. Smith, B. ve Rutigliano, T. (2010). Satış Gücünüzü Keşfedin. İstanbul: Pegasus Yayınları.

21. Spini, D. (2010). 60 Saniyede Satış. İstanbul: Martı Yayıncılık.

22. Tulgar, K. (2010). Kar Arttırma Yöntemleri. İstanbul: Alfa Yayınları.

23. Vural, B. (2004). Toplum Önünde Etkili ve Başarılı Konuşma. İstanbul: Hayat Yayınları.

24. Waugh, T. (2004). 101 Marketing Strategies. Canada: John willey \& Sons Inc.

25. Yükselen, C. (2008). Pazarlama. Ankara: Detay Yayınları.

26. Yeniçeri, T. ve Yücel, İ. (2009). Müşteri İlişkileri, Örgütsel Bağılık, Planlama, Öğrenme Yönlülük, Uyum Sağlayıcı Davranış İle Satış Performansı Arasındaki İlişkilerin İncelenmesi. Cumhuriyet Üniversitesi Iktisadi ve İdari Bilimler Dergisi, 10(1), 137 -157. 